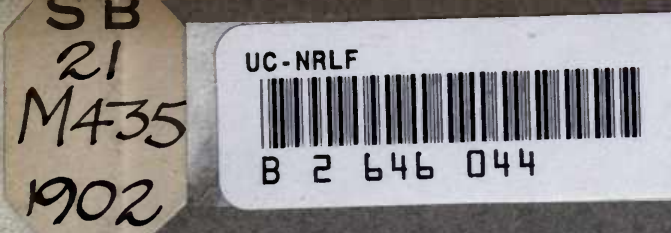




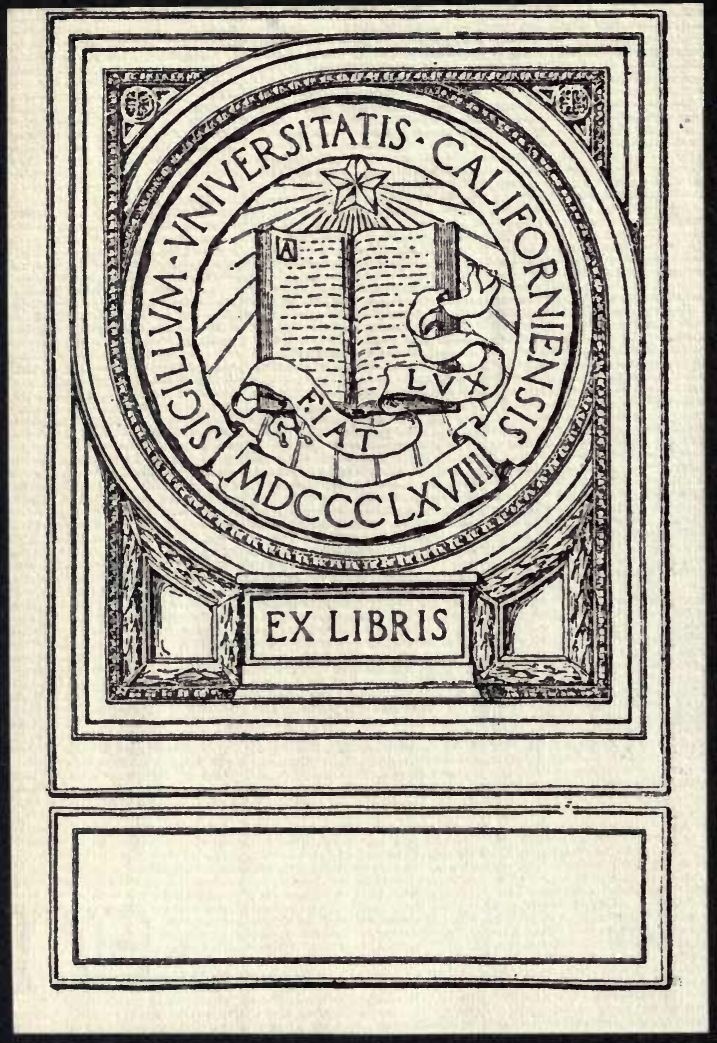




\section{CHARTER AND BY-LAWS}

OF THE

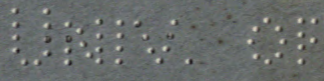

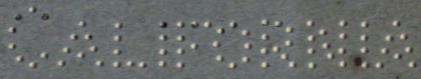

Massachusetts Horticultural 1)

\section{Society}




$$
S B 21
$$

$$
\begin{gathered}
M 435 \\
1902
\end{gathered}
$$




\section{Massachusetts Horticultural Society.}

The Committee appointed in accordance with the vote of the Society at its meeting of July 5,1902 , to consider the revision of the Society's Constitution and By-laws have given the matter much consideration, and now take pleasure in submitting to the members a draft of a code of By-laws.

They earnestly recommend to the members to be present at the

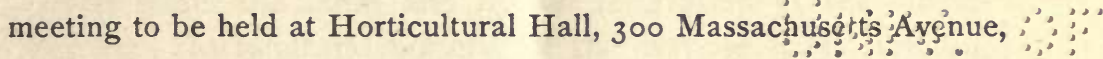
Boston, next Saturday, January 3, 1903, at 1 I $\rho^{3}$ closk, A.M., wh ḩen action will be taken on these By-laws.

Under the existing Constitution, amendments to be finally adopted must be presented at two meetings, and you will therefore be called upon to attend again at the April meeting. The Committee unanimously recommend the acceptance of these By-laws by the Society.

HENRY P. WALCOTT,

RICHARD M. SALTONSTALL,

C. MINOT WELD,

EDWIN H. JOSE,

WILLIAM H. SPOONER,

WARREN W. RAWSON,

JOHN K. M. L. FARQUHAR,

Boston, December 30, 1902.

Committee. 


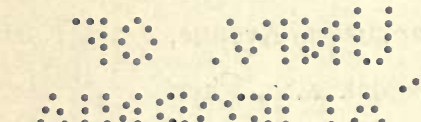

a 


\section{CHARTER OF THE SOCIETY.}

\section{AN ACT TO INCORPORATE THE MASSACHUSETTS}

HORTICULTURAL SOCIETY.

Section 1. Be it enacted by the Senate and House of Representatives in General Court assembled, and by the authority of the same, That Zebedee Cook, Jr., Robert L. Emmons, -William Worthington, B. V. French, John B. Russell, J. R. Newhall, Cheever Newhall, and Thomas G. Fessenden, their Associates and Successors, be, and they hereby are incorporated, under the name, and by the description of the Massachusetts Horticultural Society, for the purpose of enic suratying and improving the science and practice of horti, usture; promoting the amelioration of the various species 'of "trees," fruits, plants and vegetables, and the introduction of new species and varieties; with power to make by-laws not inconsistent with the Laws of the Commonwealth, for the regulation of said society and the management of the same and of its concerns; to receive donations, bequests and devises, for promoting the objects of said society; to lay and collect assessments on the members not exceeding two dollars per annum; to enforce the payment of such assessments by action for the same; to purchase and hold real estate to the amount of ten thousand dollars, and personal estate to the amount of twenty thousand dollars; to elect a treasurer, secretary and other officers, - the appointment of which shall be provided for in the by-laws of said society; the meeting for the election of such officers to be called at the times and in the manner provided in such by-laws; to empower the president, directors, comptrollers, treasurer, committees, or other officers or members, or any attorneys, agents or representatives of said society, to transact the business, manage and 
apply the funds, discharge the functions, and promote the objects thereof; to authorize any of the members or officers of said society to fill vacancies in the various offices of the same, that may happen in the intervals between the meetings of the members for choosing officers; and to commence and defend suits.

Section 2. Be it further enacted, That in case the said corporation shall, at any time, contract debts beyond their means and ability to pay at the time of contracting the same, the officers or other agents of said corporation, so contracting such debts, shall be personally liable for the same.

Section 3. Be it further enacted, That any member of said corporation may cease to be a member thereof, by giving notice to that effect to the president, treasurer, secretary, or other officers, and paying the amount due from him to the $\because \because$ sociexy $\because \because \vdots$

$\therefore: \because \because \because$. Exprow $4 . \cdot$ Be it further enacted, That the first meeting of the "mern'er" of said corporation may be called by any two or more of the persons named in the first section, by giving one week's notice, or more, by advertisement in any newspaper printed in Boston.

Section 5. Be it further enacted, That this Act may be altered or repealed at the discretion of the Legislature.

Approved June I 2, I 829.

The Acts in addition to this Act (other than those relating to Mount Auburn) are:-

1. An Act authorizing the purchase and holding of real estate to the amount of fifty thousand dollars, approved February 5,1844 .

2. An Act authorizing the purchase and holding of real estate to the amount of one hundred thousand dollars, approved April 25, 1853.

3. An Act authorizing the holding of real estate to the amount of two hundred and fifty thousand dollars, approved March 4, 1863. 


\section{CHARTER OF THE SOCIETY.}

\section{AN ACT TO INCORPORATE THE MASSACHUSETTS}

HORTICULTURAL SOCIETY.

Sectron r. Be it enacted by the Senate and House of Representatives in General Court assembled, and by the authority of the same, That Zebedee Cook, Jr., Robert L. Emmons, William Worthington, B. V. French, John B. Russell, J. R. Newhall, Cheever Newhall, and Thomas G. Fessenden, their Associates and Successors, be, and they hereby are incorporated, under the name, and by the description of the Massachusetts Horticultural Society, for the purpose of encouraging and improving the science and practice of horticulture, and promoting the amelioration of the various species of trees, fruits, plants and vegetables, and the introduction of new species and varieties; with power to make by-laws not inconsistent with the Laws of the Commonwealth, for the regulation of said society and the management of the same and of its concerns; to receive donations, bequests and devises, for promoting the objects of said society; to lay and collect assessments on the members not exceeding two dollars per annum; to enforce the payment of such assessments by action for the same; to purchase and hold real estate to the amount of ten thousand dollars, and personal estate to the amount of twenty thousand dollars; to elect a treasurer, secretary and other officers, - the appointment of which shall be provided for in the by-laws of said society; the meeting for the election of such officers to be called at the times and in the manner provided in such by-laws; to empower the president, directors, comptrollers, treasurer, committees, or other officers or members, or any attorneys, agents or representatives of said society, to transact the business, manage and 
apply the funds, discharge the functions, and promote the objects thereof; to authorize any of the members or officers of said society to fill vacancies in the various offices of the same, that may happen in the intervals between the meetings of the members for choosing officers; and to commence and defend suits.

Section 2. Be it further enacted, That in case the said corporation shall, at any time, contract debts beyond their

- means and ability to pay at the time of contracting the same, the officers or other agents of said corporation, so contracting such debts, shall be personally liable for the same.

Section 3. Be it further enacted, That any member of said corporation may cease to be a member thereof, by giving notice to that effect to the president, treasurer, secretary, or other officers, and paying the amount due from him to the society.

Section 4. Be it further enacted, That the first meeting of the members of said corporation may be called by any two or more of the persons named in the first section, by giving one week's notice, or more, by advertisement in any newspaper printed in Boston.

Section 5. Be it further enacted, That this Act may be altered or repealed at the discretion of the Legislature.

Approved June I 2, I 829.

The Acts in addition to this Act (other than those relating to Mount Auburn) are :

1. An Act authorizing the purchase and holding of real estate to the amount of fifty thousand dollars, approved February 5, I 844 .

2. An Act authorizing the purchase and holding of real estate to the amount of one hundred thousand dollars, approved April 25, I 853 .

3. An Act authorizing the holding of real estate to the amount of two hundred and fifty thousand dollars, approved March 4, 1863. 
4. An Act exempting from taxation such portions of real estate and buildings belonging to incorporated horticultural societies as are used for their offices, libraries and exhibitions, approved April 19, 1884 .

5. An Act authorizing the holding of real and personal estate to an amount not exceeding one million dollars, approved May 2, 1895. 


\section{B Y - L A W S \\ OF THE}

\section{MASSACHUSETTS HORTICULTURAL SOCIETY.}

\section{PRELIMINARY.}

These By-laws shall, except as hereinafter provided, go into effect on the morning of the first day of January, r904.

The officers of the Society provided for in Section I. of these By-laws, other than the Delegate to the State Board of Agriculture, whose terms shall begin on the first day of January, 1904, shall be elected at a meeting of the Society to be held on the second Saturday after the first Monday of November, 1903 .

The present Delegate to the State Board of Agriculture elected at the meeting held on the first Saturday of October, 1902, to serve for three years, shall hold office until the first day of January, I906, and his successor shall be elected at the annual meeting of the Society to be held in November, I905. Appropriations for prizes and gratuities to be awarded in the year 1904 shall be made at said meeting to be held on the second Saturday after the first Monday in November, 1903, on the recommendation of the existing Executive Committee; but no other appropriations shall be then made calling for any disbursements after the first day of January, 1904.

The ballots for such election shall be printed by the Secretary, and the names of candidates nominated for each office shall be printed thereon in alphabetical order, and the voting shall be as provided in Section XV. of these By-laws. 
Nominations for officers to be elected at said meeting to be held on the second Saturday after the first Monday in November, 1903, shall be made as provided in Clause 2 of Section XIV. of these By-laws, and in no other manner; and the Secretary shall, immediately on receiving them, post such nominations in some public place in the Society's building. The Secretary shall also send a notice of said meeting to every member of the Society, as provided in Section I. of these By-laws.

No officer of the Society, professor, or member of any board or of any committee, shall be elected or appointed until said meeting, for a period expiring later than the 3 Ist of December, 1903; and the existing Constitution and By-laws are hereby amended or repealed, so far as may be necessary to make this section effectual.

\section{SECTION I.}

\section{MEETINGS.}

The annual meeting of the Society for the transaction of business and for the election of officers, - namely, a President, two Vice-President's, a Treasurer, a Secretary, a Dèlegate to the State Board of Agriculture, a Board of Trustees, and a Nominating Committee,- shall be held on the second Saturday after the first Monday in November, and the officers elected shall enter upon their duties on the first day of January ensuing.

In addition to the annual meeting there shall be held a meeting at noon on the first Saturday in January in each year to be called the inaugural meeting, at which the President shall make an inaugural address, and the Treasurer and Secretary, whose terms of office expired on January first preceding, the Board of Trustees, the Library Committee, the Committee on Lectures and Publications, and every existing committee appointed by the Board of Trustees under the 
provisions of clause (8) Section IX. of the By-laws shall each make a report to the Society for the preceding year. No business except the hearing of such address and the acceptance or rejection of such reports shall be transacted at the inaugural meeting.

Special meetings of the Society may be called by order of the President, or by any five of the Board of Trustees, or upon request of fifteen members of the Society.

A notice of each meeting and of every adjourned meeting shall be mailed by the Secretary to each member at his last address appearing on the records of the Secretary at least ten days prior to the meeting; and the notice of a special meeting shall specify the business to be considered at such meeting, which shall be proposed as provided in Section II., and no business other than that specified shall be transacted thereat, and no new business shall be transacted at any adjourned meeting.

Thirty members shall constitute a quorum at any meeting of the Society.

\section{SECTION II. \\ POWERS RESERVED TO THE SOCIETY.}

The Society may, except as herein provided, by vote of its members, at any annual meeting or special meeting called as provided by Section I., transact any business lawful under its Charter and By-laws; may instruct the Trustees and other officers of the Society; and the vote of the Society shall supersede the action of any of its officers : provided, however, that acquired rights of third parties shall not be thereby impaired. No vote calling for any appropriation of money or any sale or conveyance of any of the Society's property shall be valid without the approval of the Board of Trustees, except that the Society may, by a vote of a majority of all its members, authorize such sale or conveyance of the real estate belonging to the Society without the approval of the Board of Trustees. 
The Trustees, or any five of them, or any fifteen members of the Society, may propose business to be considered at any special meeting, of which proposed business notice shall be given as provided in Section I. No sale of the Society's real estate, and no expenditure or contract therefor amounting to more than five thousand dollars for any one purpose, shall be valid and binding on the Society unless authorized by a vote of the Society.

\section{SECTION III.}

OFFICERS.

The officers of the Society shall -consist of a President, two Vice-Presidents, a Treasurer, a Secretary, a Delegate to the State Board of Agriculture, a Board of Trustees of fifteen members, a Nominating Committee of five members, and such other officers and committees as the Board of Trustees shall appoint, according to Section IX. : provided, however, that no person shall be eligible to any office unless he shall have been a member of the Society for two years preceding.

\section{SECTION IV.}

THE PRESIDENT.

The President shall be elected annually by the Society, and shall be ex officio a member of the Board of Trustees. His duties shall be to preside at the meetings of the Society and of the Board of Trustees; to preserve order; to state the business before the meeting; to state and put questions; and, in case of an equal division on any question, to give the casting vote; and to call for accounts and reports from all committees.

\section{SECTION V.}

THE VICE-PRESIDENTS.

There shall be two Vice-Presidents, who shall, except as provided in Section X., be elected by the Society on alternate 
years, and shall serve two years. In the absence of the President, the senior Vice-President present shall exercise all the authority, privileges, and powers of the President; and, in case neither the President nor either Vice-President shall be present at any meeting, the meeting shall choose a President pro tempore, who shall be invested with all the powers and authority of the President.

\section{SECTION VI.}

THE TREASURER.

The Treasurer shall be elected annually by the Society, and shall have the following powers and duties:-

(a) He shall have charge of the funds of the Society, and shall deposit the same in such bank or trust company as the Board of Trustees shall direct, where his account as Treasurer shall be kept; and all payments shall be made by check.

(b) He shall attend to the renting of the Building and the collection of the rents and other income of the Society.

(c) He shall pay prizes and gratuities upon the written order of the Board of Trustees or the chairman of any committee authorized by said Board to give such order, and shall pay no bills until audited by an officer designated by the Board of Trustees.

(d) He shall have the care and custody of the seal of the Society and of the dies for the medals; and he shall cause the medals to be struck and certificates of merit to be prepared, when required, and shall deliver them as awarded.

(e) He shall have in his safe keeping the bonds, deeds, notes, certificates of stock, and other evidences of property, unless the Board of Trustees shall otherwise direct.

$(f)$ He shall, unless the Board of Trustees shall otherwise order, make all transfers and investments, with the consent and approval of the Board of Trustees.

(g) He shall pay the taxes, insurance, interest on loans, 
and other debts, and keep a correct account of the receipts and disbursements of the Society.

(h) He shall, in January of each year, send to every annual member a bill of the amount due from him.

(i) He shall, as early in the year as possible, present to the Board of Trustees a full statement of receipts and expenditures for the preceding year. The fiscal year shall commence on the first day of January, and all assessments for the ensuing year shall be due at that time. He shall annually make a report to the society at the inaugural meeting at the close of his term of office.

(j) He shall give bond for the faithful performance of his duties in such sum and with such sureties as shall be approved by the Board of Trustees.

(k) He shall not make or issue any note or other negotiable instrument unless expressly authorized in each case so to do by the Board of Trustees who shall in each case in their vote containing such authorization provide that such note or other obligation shall not be valid or binding on the Society until countersigned by some person designated in such vote: provided, however, that he may be given authority by a general vote of the Board of Trustees to draw checks on the funds of the Society on deposit, as provided in Clause $(a)$ of this Section VI.

He shall, in the discharge of all his duties, be subject to the control of the Board of Trustees.

\section{SECTION VII.}

THE SECRETARY.

The Secretary shall be elected annually by the Society. He shall conduct the correspondence of the Society, and shall keep copies of the same in a book provided for the purpose which shall be open to the inspection of the members at any meeting. He shall receive and read all letters and papers 
addressed to the Society, and shall dispose of them as provided by the By-laws or directed by the Society or by the Board of Trustees: He shall regularly record the proceedings at every meeting and every adjourned meeting of the Society in a book to be kept for that purpose. He shall call special meetings of the Society when ordered or requested, as provided in Section I.

He shall give notice to each person of his election to office or membership in the Society. He shall record the election of every member, and report his name and residence to the Treasurer. He shall deliver to the Board of Trustees a copy of the proceedings of each meeting, whenever requested, and shall prepare and countersign all diplomas or certificates of membership.

He shall prepare for each annual election an alphabetical list of the members of the Society.

He shall, under the direction of the Committee on Lectures and Publications, act as editor of the publications of the Society, prepare them for the press, and superintend the printing thereof. He shall make notes, for publication, of meetings for discussion of horticultural subjects, and shall perform such other literary work as may be directed by the Society or the Board of Trustees, or as may not be otherwise provided for.

In the absence of the Secretary at any meeting the President shall appoint a Secretary pro tempore.

\section{SECTION VIII.}

DELEGATE TO THE STATE BOARD OF AGRICULTURE.

The term of office of the Delegate to the State Board of Agriculture shall be for three years, and he shall be chosen at the annual meeting whenever his term of office is about to expire. 


\section{SECTION IX. \\ BOARD OF TRUSTEES.}

The Board of Trustees shall consist of fifteen members, including the President and the two Vice-Presidents, who shall be members of the Board ex officiis. Four members in addition to the President and one Vice-President shall be chosen each year, except as provided in Section X., and shall serve for the term of three years.

The Board of Trustees shall hold stated meetings on the first Saturdays of January, April, and October in each year. Special meetings of the Board may be called by the President or by a call signed by any two members of the Board on at least three days' notice, which may be given by mail at the last address of the member so notified appearing on the records of the Secretary. This notice may be waived in writing. Eight members of the Board shall constitute a quorum thereof.

In the absence of action by the Society as provided in Section II., the Board of Trustees shall have and exercise the following powers and duties:-

(I) They shall have general charge and direction of the business of the Society.

(2) They shall have the care and management of the Society's real estate, and may lease the same, or any part thereof, and make all necessary repairs; but no sale of the Society's real estate, except sales of shares in real estate trusts, so called, held by the Society as part of its invested funds, shall be valid without a vote of the Society authorizing such sale.

(3) They shall have the care and management of the Society's invested funds and other personal property, with power to invest, reinvest, and transfer the same in their discretion, or they may authorize and approve transfers and investments made by the Treasurer, as provided in Section VI. They shall 
have the care of all stocks, bonds, and other personal property of the Society, but may leave the custody of the same in the Treasurer, as provided in Section VI; and they shall annually audit, or cause to be so audited, the Treasurer's accounts.

(4) They shall consider and pass upon all questions of the appropriation of money, and shall, at the annual meeting,

- recommend to the Society the amount to be appropriated for prizes and gratuities and such other appropriations as they may deem advisable during the ensuing year. They may, however, subject to the provisions of Section II., make such additional appropriations for the purposes of the Society as they deem proper.

(5) They shall appoint the following committees: a Finance Committee, a Library Committee, and a Committee on Lectures and Publications. The members of the Finance Committee shall all be members of the Board of Trustees. The members of the Library Committee and the Committee on Publications need not all be members of the Board of Trustees.

(a) The Finance Committee. - The Finance Committee shall, except as herein provided, have and enjoy all powers and duties given by this Section IX. to the Board of Trustees in relation to the care and management of the Society's property, real and personal, other than its Library.

(b) The Library Committee. - The Library Committee shall, except as herein provided, have all powers given by this Section IX. to the Board of Trustees in relation to the care and management of the Library of the Society.

(c) The Committce on Lectures and Publications. - The Committee on Lectures and Publications shall superintend all publications of the Society and have the direction in each year of six or more lectures and essays on horticultural subjects, including that provided for by the John Lewis Russell Fund.

In addition to these committees the Board of Trustees may 
appoint such other committees from among their number as they see fit, and may delegate to such committees any of their powers; but no expenditure or contract for expenditure exceeding five hundred dollars at any one time, and no appointment of committees or officers of the Society, and no election of members thereto, shall be valid or binding without the action of a majority of the full Board of Trustees at a legal meeting.

Any powers given to any 'committee by the provisions of this clause (5) and any powers delegated to any such committee by special vote of the Board of Trustees, may be withdrawn or limited by vote of said Board at any subsequent time. The Board may at any time remove any or all of the members of any such committee, and substitute others in their places.

(6) They shall appoint a Superintendent of the Building and a Librarian of the Society, and define their duties, except when these are determined by the By-laws, and may remove them or either of them, and appoint others in their stead, whenever, in their opinion, the interests of the Society shall require it. They may employ such additional assistants as they deem best, and shall determine the compensation of all officers and agents of the Society.

(7) They shall arrange for six or more exhibitions of flowers, plants, fruits, and vegetables in each year, and shall have the entire charge of all arrangements for conducting the same.

(8) They shall appoint each year the following standing committees, the members of which need not be members of the Board of Trustees: ( $a$ ) on plants and flowers; $(b)$ on fruits ; $(c)$ on vegetables. Each of these committees shall consist of three or more members. They shall also appoint each year a standing committee of five or more members on gardens. The President shall be one of this committee $c x$ officio. In addition to the standing committees named in this Clause (8) the Board of Trustees may appoint such additional 
committees as may be required for conducting special exhibitions and for awarding prizes, and may, in their discretion, appoint persons from outside the membership of the Society to act as judges to award prizes either alone or in conjunction with ahy committee.

The Board of Trustees may. delegate appropriate powers to any of the committees appointed under this Clause (8), excepting the power to appropriate money or to dispose of property of the Society. They may at any time revoke powers so delegated, and may at any time, in their discretion, remove any member of any such standing committee and substitute any other in his place.

\section{SECTION $\mathrm{X}$.}

FIRST ELECTION OF VICE-PRESIDENTS AND BOARD OF TRUSTEES.

At the first meeting at which officers are to be elected, two Vice-Presidents shall be chosen, one to hold office until the qualification of his successor chosen at the annual meeting in November, I904, and one to hold office until the qualification of his successor chosen at the annual meeting in November, 1905.

There shall also be chosen at said meeting twelve members of the Board of Trustees in addition to the President and two Vice-Presidents, so that the total number of said Board shall be fifteen. Four of said Trustees, other than the President and Vice-Presidents, shall be elected to and shall hold office until the qualification of their successors chosen at the annual meeting in November, I906; four shall be elected to and shall hold office until the qualification of their successors chosen at the annual meeting held in November, I905; and the remaining four shall be elected to and shall hold office until the qualification of their successors chosen at the annual meeting held in November, 1904. 


\section{SECTION XI.}

THE LIBRARIAN.

The Librarian shall have charge of all books, drawings, engravings, herbariums, and other articles appertaining to the Library, and shall attend to the purchase, recording, cataloguing, arranging, binding, delivering, and receiving of books : these duties to be performed under the direction of the Board of Trustees or other committee thereof duly authorized or of the Library Committee. He shall, as far as possible, assist those desiring to use the Library in their investigations.

\section{SECTION XII.}

THE SUPERINTENDENT OF THE BUILDING.

The Superintendent of the Building shall, under the general direction of the Board of Trustees, or the Finance Committee, or other committee thereof duly authorized, or under * the direction of the Treasurer, if the Board of Trustees shall so vote, have charge of the premises, and shall see that they are kept clean and in good repair, and that all Rules and Regulations in regard to their care are strictly enforced.

\section{SECTION XIII.}

VACANCIES.

Whenever a vacancy occurs in any office of the Society, such vacancy shall be filled by the Board of Trustees until the next annual meeting, when candidates shall be nominated as provided by these By-laws to fill the remaining term, if any, for which the vacancy exists. 


\section{SECTION XIV.}

NOMINATING COMMITTEE.

(I) A Nominating Committee of five members shall be elected by the Society at its annual meeting. Said committee shall nominate at least twice the number of candidates required to fill each office of the Society. Said committee shall file such nominations with the Secretary at least one month before the annual meeting. The Secretary shall, immediately on receiving such nominations, post the same in some public place in the Society's Building.

(2) Nominations for any office, in addition to those made by the Nominating Committee, may be made, by papers signed by fifteen or more members of the Society, and deposited with the Secretary at least two weeks before the annual meeting. The Secretary shall, immediately on receiving such nominations, post the same in some public place in the Society's Building.

- (3) The Secretary shall have the ballots printed under direction of the Nominating Committee. Each ballot shall state the number to be elected for each office and the names of candidates for each office shall be printed in alphabetical order. If any ballot is marked for more than the required number, the ballot shall be declared void as a vote for that office for which the excessive number is marked. Only such candidates shall be voted for as shall have been nominated as above provided in clauses (I) and (2) of this section.

\section{SECTION XV.}

VOTING.

All elections of the Society shall be by Australian ballot; and the polls shall be continuously open between the hours of twelve noon, and four in the afternoon on the day of the annual meeting. 
The President or presiding officer shall appoint a committee of three to receive, assort, and count the votes given, and report the number. A plurality shall elect, and the President shall declare who are elected.

Voting by proxy shall not be allowed at any meeting.

\section{SECTION XVI.}

MEMBERSHIPS.

Any member may propose candidates for life or annual membership to the Board of Trustees. Such proposal shall be in writing and shall be accompanied by a statement of the qualifications of such candidate for membership. On any candidate being so proposed, said Board shall cause his name and the name of the member proposing him to be posted for at least one month in some public place in the Society's Building. During said month any member may file with the Secretary a written protest against the election of said candidate, and no candidate shall be eligible against whom thirty or more such protests have been so filed. At the first meeting of the Board of Trustees held after the expiration of the month during which the name of the candidate has been so posted, his name shall be voted on by such Board; and he shall be elected by a majority of the full number of such Board so voting. The candidate so elected shall qualify himself for membership within six months from the date when notice of his election is given him, or his election shall be void.

\section{LIFE MEMBERS.}

A payment of thirty dollars shall constitute a life membership, and exempt the member from all future assessments ; and any annual member, having paid all dues, may become a life member by the payment of twenty dollars in addition thereto. 
ANNUAL MEMBERSHIP.

Every annual member, before he receives his diploma or exercises the privileges of a member, shall pay the sum of ten dollars as an admission fee, and shall be subject afterwards to an annual assessment of two dollars.

PRIVILEGES.

Each member of the Society shall be entitled to the following privileges :-

I. To be present and vote at all the meetings of the Society.

2. To have personal access to the Library, and to consult any of the periodicals, books, or plates, or to examine any of the models belonging to the Society, under rules established by the Board of Trustees.

3. To have free admission to all the exhibitions of the Society, for himself and his immediate family.

4. To receive all the publications of the Society under rules established by the Board of Trustees.

\section{SECTION XVII.}

WITHDRAWAL OR DISCONTINUANCE OR EXPULSION OF MEMBERS.

Any member may cease to be a member by giving notice to that effect to the Secretary and paying the amount due from him to the Society. Any member who shall neglect for the space of two years to pay his annual assessment, after due notice from the Treasurer, shall cease to be a member. The Treasurer shall give notice of such withdrawal or discontinuance to the Secretary, who shall erase such members' names from the list.

If any member shall dishonor the Society, or shall be guilty of any breach of good faith thereto, he may be expelled at any meeting of the Society, two-thirds of the members 
present voting therefor. But no member shall be expelled unless a written notice of the motion be served by the Secretary upon him personally, or left at his last or usual place of abode, at least twenty days before it is acted upon.

\section{SECTION XVIII. \\ HONORARY AND CORRESPONDING MEMBERS.}

The Society may, upon recommendation of the Board of Trustees, elect Honorary and Corresponding Members at any annual or special meeting, to each of whom the Secretary shall transmit a Diploma or Certificate of Election, under the seal of the Society, signed by the President and countersigned by the Secretary; and such members shall not be entitled to hold office or to vote at any meeting.

\section{SECTION XIX.}

\section{PRIZES AND GRATUITIES.}

Prizes and gratuities may be awarded by the Board of Trustees, or by such committees or judges as may be appointed by them for such purpose, to any person for the exhibition of any fruits, plants, flowers, or vegetables, either new of their kind or of uncommon excellence; or for any new and successful method of cultivating any variety of fruits, flowers, plants, trees, shrubs, or vegetables; or for any other object immediately connected with horticulture; or for the essential advancement of the objects of the Society in any other way. But no gratuity shall be awarded for any object which shall have been entered or exhibited for a prize. No award shall be made for any unworthy exhibit, and no gratuity given shall be of a larger amount than the lowest price established for the same exhibit. 


\section{SECTION XX.}

AMENDMENTS.

Amendments to the By-laws may be proposed in writing by any member of the Society to the Board of Trustees at any meeting of the Board of Trustees held at least two months before the next annual meeting of the Society, and, on being approved by a majority of the Board, shall be filed with the Secretary in their original form or as amended at least thirty days before such annual meeting, and shall subsequently be submitted to such annual meeting; or any thirty members may propose amendments to be acted upon at any annual meeting of the Society, without the approval of the Board of Trustees, by filing the amendments in writing with the Secretary thirty days at least before such annual meeting. The vote on each amendment shall be "Yes" or "No."

The Secretary shall, at least three weeks before the meeting at which the same are to be considered, mail a copy of every proposed amendment to each member of the Society at his last address appearing on the records of the Secretary.

All amendments proposed shall be printed on one ballot, with a space for voting "Yes" or "No" opposite each amendment, thus :-

\begin{tabular}{|c|c|c|}
\hline $\begin{array}{c}\text { If you wish the amendment adopted, put a cross } \\
\text { under "Yes." If not, under "No." }\end{array}$ & YES. & NO. \\
\hline (Here the subject of the amendment.) & & \\
\hline
\end{tabular}

Any amendment shall be adopted if it receives two-thirds of the votes cast. The polls shall remain open for the purpose of voting on any proposed amendments between the hours of noon and four in the afternoon, and the voting shall be by Australian ballot. 
present voting therefor. But no member shall be expelled unless a written notice of the motion be served by the Secretary upon him personally, or left at his last or usual place of abode, at least twenty days before it is acted upon.

\section{SECTION XVIII.}

HONORARY AND CORRESPONDING MEMBERS.

The Society may, upon recommendation of the Board of Trustees, elect Honorary and Corresponding Members at any annual or special meeting, to each of whom the Secretary shall transmit a Diploma or Certificate of Election, under the seal of the Society, signed by the President and countersigned by the Secretary; and such members shall not be entitled to hold office or to vote at any meeting.

\section{SECTION XIX. \\ PRIZES AND GRATUITIES.}

Prizes and gratuities may be awarded by the Board of Trustees, or by such committees or judges as may be appointed by them for such purpose, to any person for the exhibition of any fruits, plants, flowers, or vegetables, either new of their kind or of uncommon excellence; or for any new and successful method of cultivating any variety of fruits, flowers, plants, trees, shrubs, or vegetables; or for any other object immediately connected with horticulture; or for the essential advancement of the objects of the Society in any.other way. But no gratuity shall be awarded for any object which shall have been entered or exhibited for a prize. No award shall be made for any unworthy exhibit, and no gratuity given shall be of a larger amount than the lowest price established for the same exhibit. 


\section{SECTION XX.}

AMENDMENTS.

Amendments to the By-laws may be proposed in writing by any member of the Society to the Board of Trustees at any meeting of the Board of Trustees held at least two months before the next annual meeting of the Society, and, on being approved by a majority of the Board, shall be filed with the Secretary in their original form or as amended at least thirty days before such annual meeting, and shall subsequently be submitted to such annual meeting; or any thirty members may propose amendments to be acted upon at any annual meeting of the Society, without the approval of the Board of Trustees, by filing the amendments in writing with the Secretary thirty days at least before such annual meeting. The vote on each amendment shall be "Yes" or "No."

The Secretary shall, at least three weeks before the meeting at which the same are to be considered, mail a copy of every proposed amendment to each member of the Society at his last address appearing on the records of the Secretary.

All amendments proposed shall be printed on one ballot, with a space for voting "Yes" or "No" opposite each amendment, thus :-

\begin{tabular}{|c|c|c|}
\hline $\begin{array}{c}\text { If you wish the amendment adopted, put a cross } \\
\text { under "Yes." If not, under "No." }\end{array}$ & YES. & NO. \\
\hline (Here the subject of the amendment.) & & \\
\hline
\end{tabular}

Any amendment shall be adopted if $\cdot$ it receives two-thirds of the votes cast. The polls shall remain open for the purpose of voting on any proposed amendments between the hours of noon and four in the afternoon, and the voting shall be by Australian ballot. 



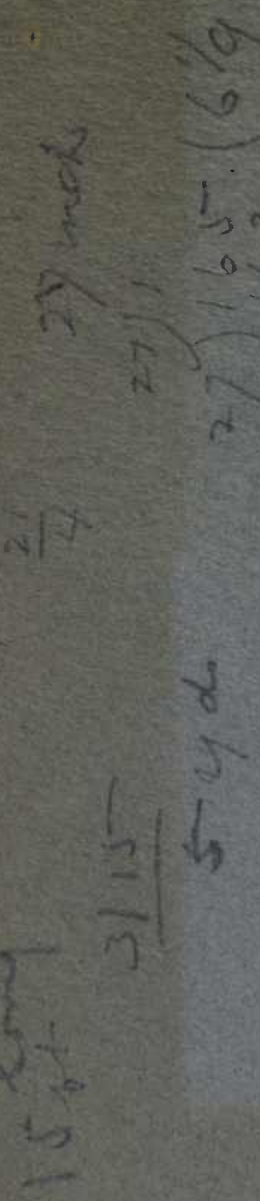

क)

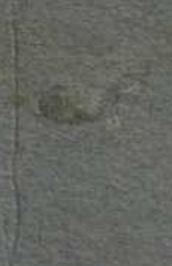




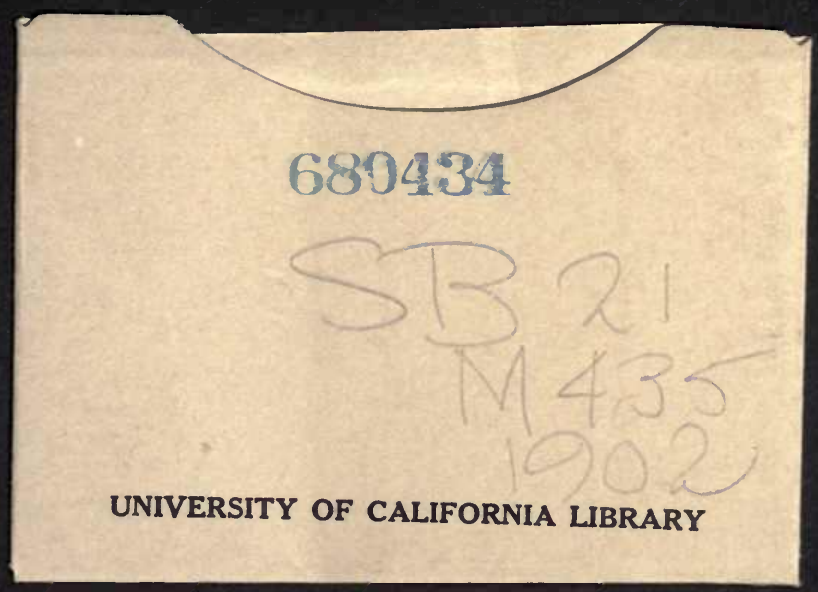


